\title{
TREATMENT OF WATER FROM IRRIGATION DRAINAGE BY MULTIMEDIA FILTRATION
}

\author{
${ }^{*}$ Shymaa M. Lazim ${ }^{1}$
}

Seroor A. Khaleefa Ali ${ }^{2}$

1) M.Sc student, Environmental Engineering Department, Mustansiriyah University, Baghdad, Iraq.

2) Asst. Prof. Environmental Engineering Department, Mustansiriyah University, Baghdad, Iraq.

\begin{abstract}
In this research, the possibility of water treatment for agricultural irrigation drainage channels was studied included Al-Dawoodi main agriculture irrigation water channel and the KSD main agriculture irrigation water channel polluted with the sewage water. The treatment was carried out using multi-media filtration technology with (three-layer) (commercial coal, coarse sand and mix ion exchange) at three flow rates $(0.24,0.32,0.48) \mathrm{m}^{3} / \mathrm{hr}$ for contact time (two hours), the comparing of analysis results before and after treatment showed that the best removal for both channels was obtained from the lowest flow rate $\left(0.24 \mathrm{~m}^{3} / \mathrm{hr}\right)$ after contact time (two hours) for (EC, TDS, TSS, COD, BOD heavy metals ( $\left.\mathrm{Na}, \mathrm{Mg}, \mathrm{Ca}, \mathrm{Cl}, \mathrm{So}_{4}\right)$ ) as $\mathrm{KSD}$ water channel by $(67 \%, 61.1 \%, 95.2 \%, 82.6 \%, 81 \%, 65.2 \%, 73.3 \%, 62 \%$, $58.2 \%, 62.2 \%)$, respectively, and for Al- Dawoodi water channel by $(60 \%, 50.2 \%, 94.1 \%, 84.4 \%, 85.1 \%, 61 \%, 60 \%$, $63 \%, 56 \%, 58 \%)$, respectively, also improves the SAR while $\mathrm{pH}$ before and after treatment was within Irrigation standards. Then the results were compared with the internationally approved standards for irrigation.
\end{abstract}

Keywords: Al-Dawoodi, KSD channel, Irrigation, Filtration.

\section{Introduction}

Water is one of the most important elements in creating and developing life. Water is a vital resource for the survival of living beings for the sustainable benefit of all present and future living materials. Therefore, its treatment and reuse is an important economic resource [1].

In light of the global water crisis for the high demand for agricultural production, the importance of making use of available natural environmental resources and reuse in proportion to agricultural requirements [2]. Recycling and treating polluted water sources (sanitation or industrial, etc.) represents an important step to reduce the risk of pollution water, thus ensuring water sustainability [3].

Agricultural irrigation drainage channels maintain the physical, chemical, and biological soil properties. The total amount of water for agricultural drainage channels in Iraq is estimated at 6.6 billion meters/year [4], these channels are among the development projects that operate to transfer salty water contaminated with fertilizers and pesticides from agricultural lands and to preserve the permanence and characteristics of the soil [5].

Filtration process represents by a physical or mechanical process used to separate solids from liquids by introducing a medium through which 
the filtering takes place. The filtration depends on the filter layer materials that are different fine particles and different pore sizes of the material such as (sand, natural stone fibers, and others). Multi-media filters are also used to clean liquid wastes from primary and septic tanks [6].

Filtration is defined as the process of removing harmful water pollutants such as suspended solids and remove of microorganisms bypassing the liquid through a porous filtration medium. The efficiency of the filter depends on the depth and quality of filter material, it is considered a highly effective physical process in removing various water pollutants, which is evidenced the removal of it by parameter analyses (total suspended solids, dissolved solids, $\mathrm{BOD}_{5}, \mathrm{COD}$, color, etc) [7].

Multi-media filters are effectively used in water treatment as it reduces turbidity and eliminates unwanted plankton, odors, and other pollutants. The filter media consists of multiple layers (sand, coal, etc.), the diversity of layers increases the efficiency of filters to purify and remove various pollutants, including heavy elements [8], so the choice of filter layer materials is an important part of design multimedia for high removal efficiency [9]. Multimedia filtration is considered economically feasible and environmentally friendly [7].

A mixed ion exchange resin with multi-media filter layers has also been used as ion exchange resins which they polymers that can exchange ions inside the polymer with other ions in a solution that passes through them, it is used to purify water and remove the mineral content completely. It has the advantage of resins (long life, cheap maintenance), which is a very environmentally friendly process, dealing only with the materials in the water [10].
In Previous studies on treatment agricultural irrigation drainage channels for irrigation purpose:

In a study that included the treatment of one of the agricultural irrigation drainage channels in the United States - Florida for reuse into agricultural purposes, the study focused on treating (COD, TSS, phosphorous removal) [11].

A study in Egypt conducted about the possibility of reusing the water of agricultural drainage channels for irrigation purposes. The study focused on concentrations of heavy metal because of its fundamental role in determining the suitability of the water used for irrigation and obtained that using drainage water without treatment is not safe for vegetables, thus doesn't be suitable for human and animal consumption [12].

The main agricultural water drainage channel (Almasabu general) was studied about the physical and chemical properties of the channel's water, including $\mathrm{pH}$, salinity and hardness, the study was showed that the water channel has high salinity and hardness, while $\mathrm{pH}$ was within the required limits [13].

The study of the agricultural water drainage channel (the main eastern drainage) included discussing the effect of the water channel that disposal on the chemical and physical properties of the Euphrates River, it was concluded that untreated water increases the values of permeability, salinity, basicity, hardness, and carbon dioxide while reducing turbidity, $\mathrm{pH}$ values [14].

The study of the main agricultural the Al-Ishaqi water drainage channel discussed the possibility of desalination of the water channel for reuse in irrigation. [15]. 
A study of the water agricultural irrigation drainage channel of Alhifar in Diwaniya was conducted, including some physical, chemical properties, the concentration of some heavy elements, $\mathrm{pH}$, total dissolved solids, electrical conductivity (EC), and $\mathrm{BOD}_{5}$. The result showed that $\left(\mathrm{pH}\right.$, total dissolved solids, $\left.\mathrm{BOD}_{5}\right)$ were within the permissible limits, while electrical conductivity and heavy elements differ according to the seasons of cultivation and fertilizers used [16].

A study that included assessing the efficiency of irrigation and drainage projects in the Kifl region, it found the importance of the channel in preserving the soil from the accumulation of salt in it and the channel operates in all its branches across agricultural lands at a rate medium efficiency [17].

Through research for studies of agricultural drainage channels understudy with their official approved names (KSD and Al-Dawoodi), no studies on the two channels were found, only at study [18] was discussed about agricultural irrigation drainage channels in the Rashidiya and Hosseinieh regions in Baghdad, as the two channels pass within it, the researcher addressed investigation of the quality of water channels and its suitability for irrigation purposes, concluded that water channels contain high levels of salt concentrations and chemical elements chlorides and magnesium.

KSD is the official name of the agricultural irrigation drainage channel as defined at the Ministry of Water Resources.

In Previous studies of using multi-media filtration for water treatment:

The multi-media filtration technique was used in a study to purify the polluted water, including a layer of (sand, gravel, clay, and coal), it found the efficiency of multi-media filtration in removing calcium and phosphorous [19].

A study that found the use of a mixed ion exchange layer leads to effective results in the exchange of ions (anion and cation), it indicated that mixed ion exchange can operate to reduce the deposition of soluble minerals, calcium, sulfate, and magnesium [20].

A study was conducted to use ion exchangers in water purification, as it was proven that the exchanges have an effective ability to remove toxic ions and reduce the electrical conductivity (EC) of the permissible limits [21].

A study was conducted on the efficiency of using the activated carbon layer, the efficacy of the activated carbon was achieved in removing $\mathrm{BOD}_{5}, \mathrm{COD}[22]$.

In a study using multi-media filtration with layers (sand, gravel, and coal) to treat polluted water, it found the high efficiency of the filter layers in removal $\mathrm{BOD}_{5}$ and $\mathrm{COD}$ [23].

The aim of this study comes from the importance of treating the water of the two main agricultural irrigation drainage channels (KSD and Al-Dawoodi) to reuse for irrigation purposes, thus achieved water sustainability and reduce agricultural and other pollutants from both channels that flow into Tigris River and the Diyala Bridge river, and that will be returned on reducing environmental damage. Also, the purpose of water channels treatment using a multi-media filtration technology since this technique uses several layers of material with locally available and low cost involved in remove pollutants with high efficiency, very effective, and the possibility of re-use materials layers, thus it considers environmentally friendly [24]. 


\section{Material and Methods}

\subsection{Description of The Study Area}

Agricultural irrigation channels drainage water is of great importance in various regions of the world, as it contributes effectively to remove excess water from the need of plants, soil and reducing its damages caused by long-term it remains in the soil, thus the drainage channels maintain the physical, chemical and biological soil properties [25]. The channels under study station included

\subsubsection{Al-Dawoodi main agricultural irrigation drainage water channel}

Al-Dawoodi channel includes areas AlRashidiya, north of Baghdad, to the lands of Diyala Governorate, with a length of $27.5 \mathrm{~km}$, the irrigation water of agriculture area flows into the channel through the sub-drainage channel. The water channel flows from both ends in the Tigris River as shown in "Fig. 1".

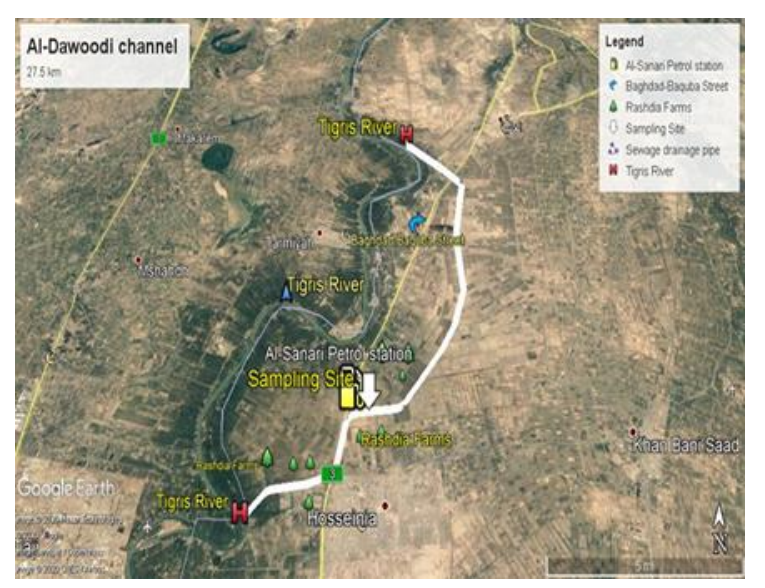

Figure 1. Path of Al-Dawoodi main agricultural irrigation drainage water channel (Google earth).

\subsubsection{KSD main agricultural irrigation drainage water channel}

The water of this channel represents agricultural irrigation drainage water mixed with sewage water from the neighboring lands and the water of Al-Sadr Gas Power Station, the channel extends from the north of Baghdad at Al Jazeera area to the east of Baghdad with a length of 25 $\mathrm{km}$, irrigation water flows to it through subdrainage channels. Water flows into the Tigris River from the north, and from the east, it flows into Bridge Diyala river as shown in "Fig. 2".

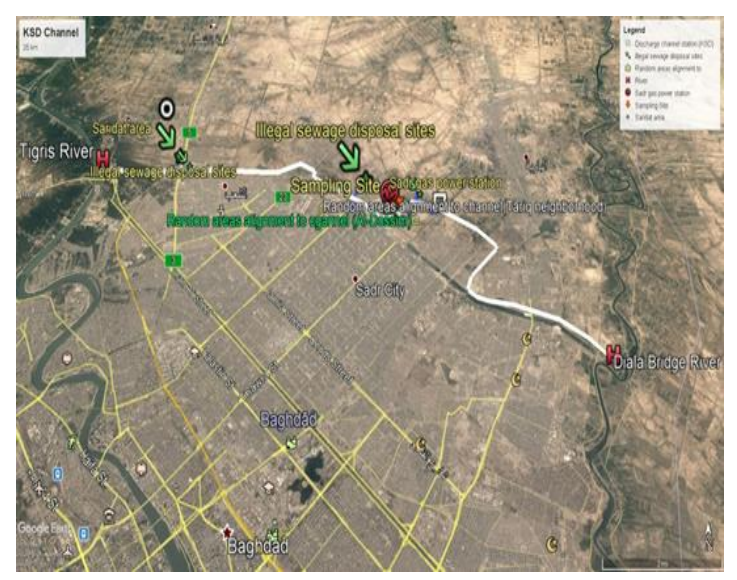

Figure 2. Path of KSD main agricultural irrigation drainage water channel (Google earth).

\subsection{Experiment and Sampling Procedure}

The experiment included sampling from AlDawoodi drainage channel at the station located within latitude $33^{\circ} 32^{\prime} 35.21$ "N, Longitude 44 - 20'51.56" E, near Al-Sanary Gas Station at (996 m), either KSD channel sampling was at the station located at latitude $33^{\circ} 25^{\prime} 57.73$ north and longitude $44^{\circ} 20^{\prime} 45.74$ "east. Water samples were collected and stored in plastic bottles.

\subsubsection{Design of multi-media filtration}

Multi-media filtration operate is designed with a continuous water recycling system shown in "Fig. 3" for each water channel (KSD and AlDawoodi) separately, includes plastic basins (60 $\mathrm{cm}$ in height) with layers of material from the bottom. Cotton cloth, commercial coal $(10 \mathrm{~cm})$ followed by a coarse sand layer $(10 \mathrm{~cm})$, and then at the top the mixed ion exchanger layer $(10 \mathrm{~cm})$ shown in "Fig. 4" and properties in 
"Table 2", as installing sprinklers with holes, faucet, and hoses plastic connected to operate with water circulation in the basins using an electric water pump with a capacity of $\left(1 \mathrm{~m}^{3} / \mathrm{hr}\right)$ installed in a plastic basin directly below the filter material basin with a height of $40 \mathrm{~cm}$. The experiment was operated using the water sample (4 liters) at three flow rates $(0.24,0.32,0.48)$ $\mathrm{m}^{3} / \mathrm{hr}$ for continuous contact time for (two hours), with the analyses of ( $\mathrm{pH}, \mathrm{EC}, \mathrm{TDS}$, TSS) every (10 minutes) during the contact time (two hours), then determine the flow rate at which the best removal results of the pollutant was achieved. After that tests were performed for $\left(\mathrm{COD}, \mathrm{BOD}_{5}\right.$, and heavy metal $(\mathrm{Na}, \mathrm{Mg}, \mathrm{Ca}$, $\left.\mathrm{Cl}, \mathrm{So}_{4}\right)$ ) after the total specified contact time (two hours) for the experiments. The details of the equipment used for analyses shown in "Table 3".

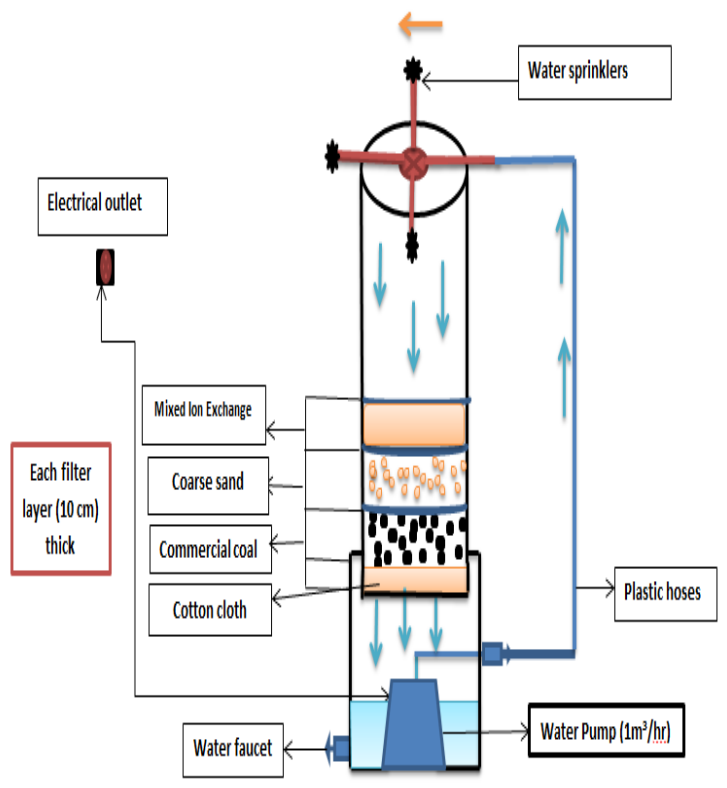

Figure 3. Schematic diagram of the multi-media filters system.

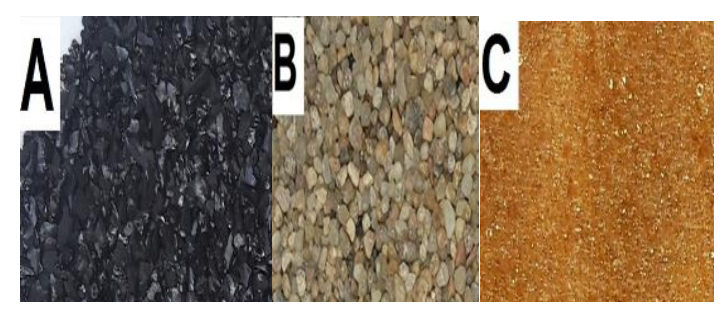

Figure 4. The material of multi-media filtration. (A) Commercial coal. (B) Coarse sand. (C) Mixed ion exchange.

The entry of water molecules through the layers of the multi-media filtration can be illustrated in general in "Fig. 5" into the filter layer.

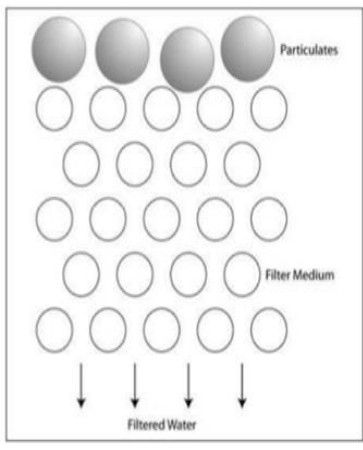

(A)

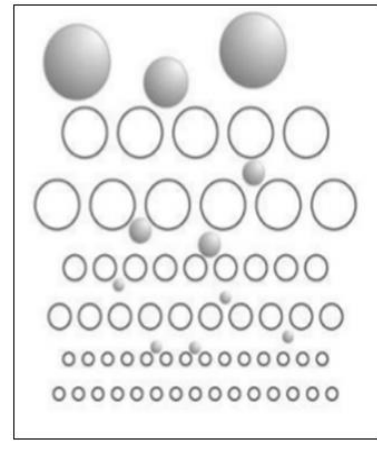

(B)
Figure 5. (A) water particulates enter the filter layers. (B) Water filtering between layers of Multi-Media filter [26].

Table 2. properties of multi-media filtration material

\begin{tabular}{cc}
\hline $\begin{array}{c}\text { Material } \\
\text { commercial }\end{array}$ & Properties \\
& Density $\left(114 \mathrm{lbs} / \mathrm{ft}^{3}\right)$ \\
$\mathrm{pH}: 9.4$ \\
Coarse sand & Effective Size: $1 / 8^{\prime \prime}-2$ 1/2" \\
& Density: $100 \mathrm{lbs} / \mathrm{ft}^{3}$ \\
Mixed ion & Cation component: Sulfonic \\
exchange & acid \\
& Anion component: \\
& Trimethylamine \\
& Volume ratio: Cation \\
& /Anion: $50 / 50 \%$ \\
\hline
\end{tabular}


Table 3. Instrument use in water analyses

\begin{tabular}{cc}
\hline Instrument & Details \\
pH meter & WTW-PH3110, Germany \\
(EC) meter & Cond-3110, Germany \\
Electric Oven & Memmert/Germany \\
TDS meter & COM-100, Germany \\
Atomic-absorption & Shimadzu AA-7000 Japan \\
Spectrophotometer & \\
AAS & \\
Chemical oxygen & Lovibond ET 125 \\
demand (COD) & \\
Thermoreactor & \\
COD photometer & Lovibond checks it direct \\
& COD VARIO \\
BOD & WTW- Germany \\
\hline
\end{tabular}

\subsubsection{Analytical measurement for water}

Conducting treatment for polluted irrigation water is among the priorities to preserve the soil. Analysis of $\mathrm{pH}$ is important for irrigation water as its height level leads to causes height the $\mathrm{pH}$ of the soil, thus affects the concentration of calcium carbonate and begins to be sedimentation and accumulation by the subsurface layer, also it affects the operation of irrigation systems and their erosion [27]. Analyses of Electrical conductivity (EC), total dissolved solids (TDS) and heavy metal (Na, $\mathrm{Mg}, \mathrm{Ca}$ ) are important that reflect the salinity thus the harmful increase of it on the soil, as the elements of sodium, magnesium, and calcium affect the SAR rate, causing a high percentage of sodium concentration to the calcium and magnesium concentration, thus depositing it in its pores and on its surface. The increased concentration of chlorides $(\mathrm{Cl})$ and sulfates $\left(\mathrm{So}_{4}\right)$ also causes toxic effects of soil and plants [28]. Also, the height level of the chemical oxygen demand (COD) affects the soil damage as it expresses the amount of organic pollutants present in the water, which determines the quality and suitability of the water quality [29]. The biochemical oxygen demand test $\mathrm{BOD}_{5}$ is also an important indicator of organic matter, wherein high value in water, it is consumed to decompose organic matter and create anaerobic decomposition process that results in the consumption of soil, iron, manganese and sulfate elements for oxygen to reduce oxidation potential and ultimately compounds are formed that disrupt plants' absorption of nutrients [30]. Also, the disposal of total suspended solids in irrigation water is very important, as the increasing accumulation of suspended substances in the irrigation water pumping pipeline network leads to their blockage [31].

The result of water analysis before treatment shown in "Table 4" showed the difference between water properties for KSD and AlDawoodi channels at station study, KSD water station contain agriculture irrigation polluted (mixed) with sewage water that disposal on it from the neighboring lands and Al-Sadr Gas Power Station, while Al-Dawoodi water station carried agriculture irrigation water, therefore observed that salts expressed (EC, TDS, Ca, Na, $\mathrm{Mg}, \mathrm{Cl}$, So4) in KSD water less than AlDawoodi channel, also, $\mathrm{COD}$ and $\mathrm{BOD}_{5}$ indicate that organic pollutants in Al-Dawoodi less than KSD, so the TSS showed that suspended solids in Al-Dawoodi more than twice KSD. SAR depended on the concentration of ( $\mathrm{Na}, \mathrm{Ca}, \mathrm{Mg})$, while $\mathrm{pH}$ value within acceptable standards for irrigation.

Table 4. Water analysis before treatment (KSD and Al Dawoodi channel

\begin{tabular}{cccc}
\hline & $\begin{array}{c}\text { Measure } \\
\text { unit }\end{array}$ & KSD & Al Dawoodi \\
$\mathrm{pH}$ & --- & 7.9 & 8.4 \\
$\mathrm{EC}$ & $\mu \mathrm{s} / \mathrm{cm}$ & 2290 & 4280 \\
$\mathrm{TDS}$ & $\mathrm{mg} / \mathrm{l}$ & 1493 & 3210 \\
$\mathrm{TSS}$ & $\mathrm{mg} / \mathrm{l}$ & 300 & 500 \\
$\mathrm{Ca}$ & $\mathrm{mg} / \mathrm{l}$ & 275 & 455 \\
$\mathrm{Na}$ & $\mathrm{mg} / \mathrm{l}$ & 198 & 222 \\
$\mathrm{Mg}$ & $\mathrm{mg} / \mathrm{l}$ & 262 & 300 \\
\hline
\end{tabular}




\begin{tabular}{cccc}
\hline $\mathrm{Cl}$ & $\mathrm{mg} / \mathrm{l}$ & 275 & 344 \\
$\mathrm{So}_{4}$ & $\mathrm{mg} / \mathrm{l}$ & 320 & 400 \\
$\mathrm{COD}$ & $\mathrm{mg} / \mathrm{l}$ & 287 & 192 \\
$\mathrm{BOD}_{5}$ & $\mathrm{mg} / \mathrm{l}$ & 199 & 134 \\
$\mathrm{SAR}$ & --- & 12.08 & 11.4 \\
\hline
\end{tabular}

The result of water before and after treatment compared with the international approved standard for irrigation shown in "Table 5"

Table 5. International standards for irrigation

\begin{tabular}{ccccc}
\hline & $\begin{array}{c}\text { Iraqi } \\
\text { standards }\end{array}$ & $\begin{array}{c}\text { FAO } \\
\text { standards }\end{array}$ & WHO & $\begin{array}{c}\text { Standards } \\
\text { wastewater } \\
\text { treated }\end{array}$ \\
pH & $6.5-8.5$ & $5-9$ & $6.5-8.5$ & $4-6,8$ \\
$\mathrm{EC}$ & 2000 & 2000 & 2000 & --- \\
$\mathrm{TDS}$ & --- & --- & $<2000$ & 2500 \\
$\mathrm{TSS}$ & 100 & 45 & --- & 40 \\
$\mathrm{Ca}$ & --- & --- & 200 & 450 \\
$\mathrm{Na}$ & --- & --- & --- & 250 \\
$\mathrm{Mg}$ & --- & --- & 50 & 80 \\
$\mathrm{Cl}$ & 350 & 250 & 300 & --- \\
$\mathrm{So} 4$ & 400 & 500 & --- & --- \\
$\mathrm{SAR}$ & $6-9$ & $6-9$ & --- & $6-9$ \\
$\mathrm{COD}$ & 150 & 90 & --- & 100 \\
$\mathrm{BOD}_{5}$ & Less 5 & 3 & --- & 40 \\
\hline
\end{tabular}

Source: Iraqi standards and FAO standards [ 32], WHO [ 33 ]. Standards wastewater treated [34].

The suitability of KSD and Al-Dawoodi water channels for irrigation before treatment was compared with the lowest and highest permissible rate at approved standards as demonstrated in "Table 6".

Table 6. Classify water analysis before treatment with approval irrigation standards

\begin{tabular}{|c|c|c|}
\hline & KSD & Al-Dawoodi \\
\hline $\mathrm{pH}$ & Allowable & Allowable \\
\hline $\mathrm{EC}$ & $\begin{array}{c}\text { Not } \\
\text { allowed }\end{array}$ & Not allowed \\
\hline TDS & Allowable & Not allowed \\
\hline TSS & $\begin{array}{c}\text { Not } \\
\text { allowed }\end{array}$ & Not allowed \\
\hline $\mathrm{Ca}$ & Allowable & Not allowed \\
\hline $\mathrm{Na}$ & Allowable & Allowable \\
\hline $\mathrm{Mg}$ & $\begin{array}{c}\text { Not } \\
\text { allowed }\end{array}$ & Not allowed \\
\hline
\end{tabular}

\begin{tabular}{ccc}
\hline $\mathrm{Cl}$ & Allowable & Not allowed \\
$\mathrm{So}_{4}$ & Allowable & Allowable \\
$\mathrm{SAR}$ & Not & Not allowed \\
& allowed & \\
$\mathrm{COD}$ & Not & Not allowed \\
& allowed & Not allowed \\
$\mathrm{BOD}_{5}$ & Not & allowed \\
& \\
\hline
\end{tabular}

\section{Results and discussion}

The results of the water analysis showed the treatment for both water channels (KSD and AlDawoodi) using multi-media filtration with (continuous water recycling system) at flow rates $(0.24,0.32,0.48) \mathrm{m}^{3} / \mathrm{hr}$ through contact time (two hours) led to decreases in $\mathrm{pH}$ and removal of (EC, TDS, TSS, COD, $\mathrm{BOD}_{5}$ and heavy metal $\left(\mathrm{Na}, \mathrm{Mg}, \mathrm{Ca}, \mathrm{Cl}, \mathrm{So}_{4}\right)$ from the original values, the high efficiency for removal was achieved at the lowest flow rate $(0.24$ $\mathrm{m}^{3} / \mathrm{hr}$ ) after expiration the total contact time (two hours) for the two channels, therefore all analysis was done at $\left(0.24 \mathrm{~m}^{3} / \mathrm{hr}\right)$ where:

pH: The pH value is shown in "Fig. 6" of both water channels decreased from (7.9 to 6.8) for KSD channel and (8.4 to 7.3) for Al-Dawoodi channel within approved standards, the decrease can be explained to the combined effect of the filter layers as the coal layer increases the $\mathrm{pH}$ due to its base surface [35] that mentioned in its specifications in the "Table 2", the coarse sand layer also increases the $\mathrm{pH}$ [36] as water molecules are divided into hydrogen $\left(\mathrm{H}^{+}\right)$and hydroxyl ion $\left(\mathrm{OH}^{-}\right)$, forming hydroxyl as a higher percentage causing an increase in $\mathrm{pH}$, while due to the strength of the mixed ion exchange layer in the exchange of cations, where calcium and magnesium ions replace hydrogen ions, hydrogen is released at a higher rate than the hydroxyl release due to anion exchange reactions causing the $\mathrm{pH}$ to decrease [37]. 
$\mathrm{EC}$, TDS, the concentration of $(\mathrm{Na}, \mathrm{Ca}, \mathrm{Mg}, \mathrm{Cl}$, $\left.\mathrm{So}_{4}\right)$ :

The removal efficiency in EC, TDS, and concentration of $\left(\mathrm{Ca}, \mathrm{Na}, \mathrm{Mg}, \mathrm{Cl}, \mathrm{So}_{4}\right)$ are shown in "Table 5" and "Fig. 7", "Fig. 9", "Fig. 10" and "Fig. 11" classified with approved standards for KSD and Al-Dawoodi channels except for $\mathrm{Mg}$ concentration for Al-Dawoodi water channel. The removal is due to the role of the ion exchanger layer during contact time in removing ionic impurities for all groups of small and large pollutants because they have a high ability to interchange, the cation and anion exchange resin is closely related to one mixture which creates a stronger driving force. Since the ion exchanger is mixed as the exchange between the cation and the anion exchanger is close, the cation exchanger replaces the hydrogen ion with calcium and magnesium ((causing the salts to increase in water and raise the value of $\mathrm{EC}$, TDS)) during the release of sodium ion ( $\mathrm{Na}$, the ion exchanger replaces the hydroxide ions $\mathrm{OH}^{-}$with chloride and sulfates present as minerals and releases chlorine, as a result, the sodium ion binds with the chlorine ion to form food salt $(\mathrm{NaCl})$, which is not considered hardness. Thus, salts and minerals decrease in water and this is consistent with $[38,19]$.

Also, Zidan, Salih, and Waheed [35] demonstrated through experience the role of commercial coal in the removal of TDS, concentration ( $\mathrm{Na}, \mathrm{Ca}, \mathrm{Mg}, \mathrm{So} 4, \mathrm{Cl})$ and reducing salts effectively.

Table 5. Removal efficiency of (EC, TDS, $\mathrm{Ca}, \mathrm{Na}$,

\begin{tabular}{ccccc}
\multicolumn{5}{c}{$\left.\mathrm{Mg}, \mathrm{Cl}, \mathrm{So}_{4}\right),\left(0.24 \mathrm{~m}^{3} / \mathrm{hr}\right)$} \\
\hline \multicolumn{4}{c}{ KSD channel } \\
& $\begin{array}{c}\text { Value } \\
\text { after }\end{array}$ & $\begin{array}{c}\text { Al-Dawoodi channel } \\
\text { removal } \\
\text { treatment }\end{array}$ & $\begin{array}{c}\text { Value } \\
\text { after } \\
\text { treatment }\end{array}$ & $\begin{array}{c}\text { \% of } \\
\text { removal }\end{array}$ \\
EC & 756 & $67 \%$ & 1712 & $60 \%$ \\
$\mathrm{TDS}$ & 580 & $61.1 \%$ & 1599 & 50.2 \\
$\mathrm{Ca}$ & 105 & $62 \%$ & 168 & $63 \%$ \\
$\mathrm{Na}$ & 69 & $65.2 \%$ & 86 & $61 \%$ \\
\hline
\end{tabular}

\begin{tabular}{ccccc}
\hline $\mathrm{Mg}$ & 70 & $73.3 \%$ & 120 & $60 \%$ \\
$\mathrm{Cl}$ & 115 & $58.2 \%$ & 151 & $56 \%$ \\
$\mathrm{So}_{4}$ & 121 & $62.2 \%$ & 168 & $58 \%$ \\
\hline
\end{tabular}

TSS: The removal efficiency of TSS value shown in "Fig. 8" from (300 to 14.4) for KSD channel and (500 to 24.6) for Al-Dawoodi channel within approved standards, that removal can be explained by the coarse sand layer as it removal the total suspended solids $[39,40]$, also James [40] demonstrated the role of slowing flow rate with contact time in the removal of total suspended solids.

Al-Abed, Abdulla, and Zahrawi [31] obtained through their study for treating polluted water that the high-efficiency role of commercial coal in the removal of TSS.

SAR: The value of SAR shown in "Fig. 13" is calculated from "equation (1)" :

$S A R=\frac{N a}{\sqrt{(C a+M g) / 2}}$

$\mathrm{SAR}$ value is related to the concentration of ( $\mathrm{Na}, \mathrm{Ca}, \mathrm{Mg}$ ), then the low concentration of sodium, magnesium, and calcium has a positive return on the water for irrigation purposes, the SAR value (12.08) for KSD channel and (11.4) for Al-Dawoodi channel, it's classified within approved standards.

$\mathrm{COD}$ and $\mathrm{BOD}_{5}$ : The removal efficiency of $\mathrm{BOD}_{5}$ and $\mathrm{COD}$ in the two water channels shown in "Table 6" and "Fig. 12" can be explained by the combined role of the filter layers, where the use of sand and coal has resulted in highly efficient removal [41].

The use of the coal layer with the mixed ion exchange resulted in a very high decrease in the COD value [42]. It is classified within approved standards. 
Table 6. Removal efficiency (COD, $\left.\mathrm{BOD}_{5}\right),(0.24$ $\left.\mathrm{m}^{3} / \mathrm{hr}\right)$

\begin{tabular}{ccccc}
\hline & \multicolumn{2}{c}{ KSD channel } & \multicolumn{2}{c}{ Al-Dawoodi channel } \\
& $\begin{array}{c}\text { Value } \\
\text { after } \\
\text { treatment }\end{array}$ & $\begin{array}{c}\text { \% of } \\
\text { removal }\end{array}$ & $\begin{array}{c}\text { Value } \\
\text { after } \\
\text { treatment }\end{array}$ & $\begin{array}{c}\text { \% of } \\
\text { removal }\end{array}$ \\
COD & 50 & $82.6 \%$ & 30 & $84.4 \%$ \\
BOD $_{5}$ & 38 & $81 \%$ & 20 & $85.1 \%$ \\
\hline
\end{tabular}

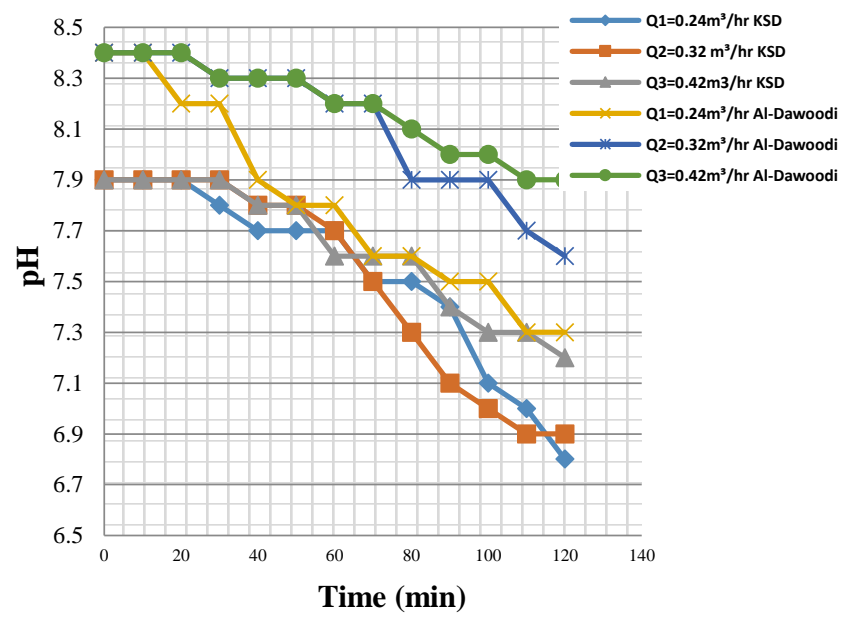

Figure 6. The decrease in $\mathrm{pH}$ for (KSD and $\mathrm{Al}-$ Dawooodi)

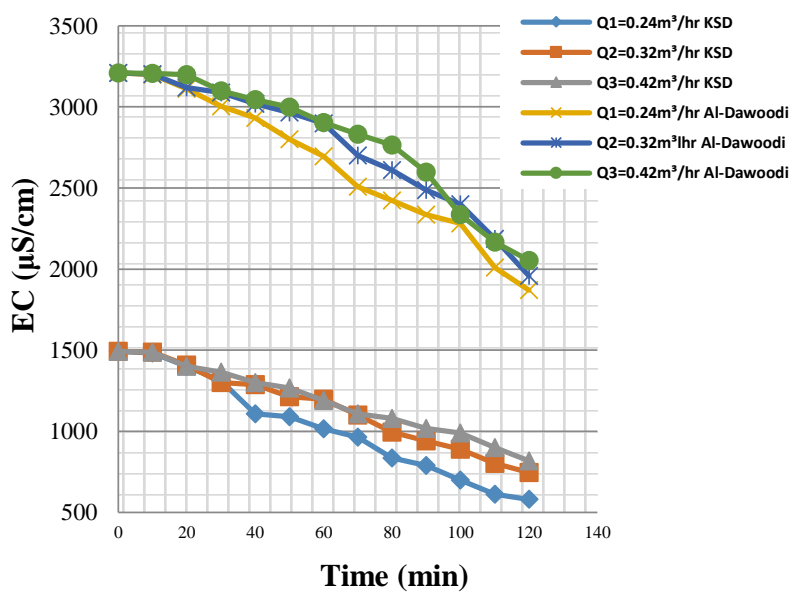

Figure 7. The removal EC for (KSD and Al-Dawooodi).

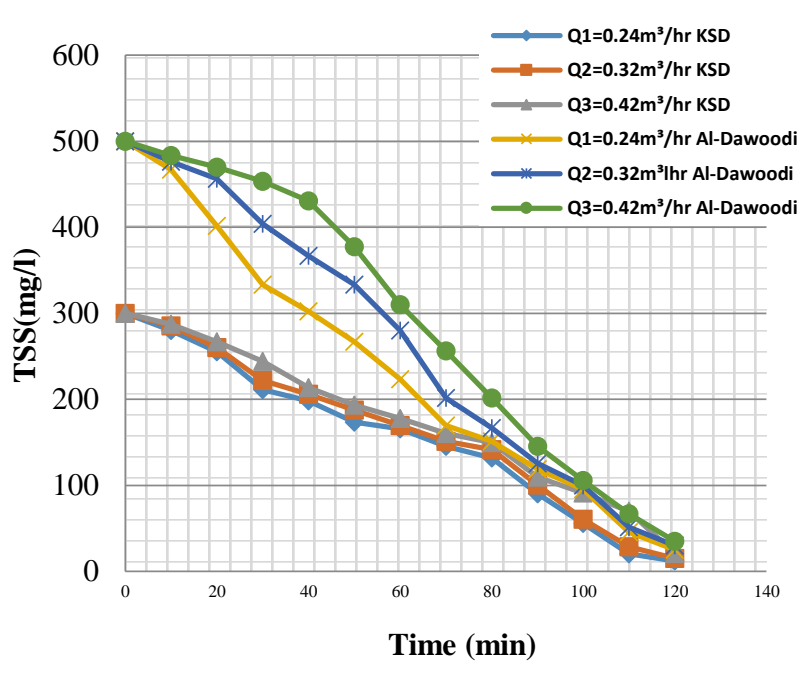

Figure 8. The removal TSS for (KSD and Al-Dawooodi).

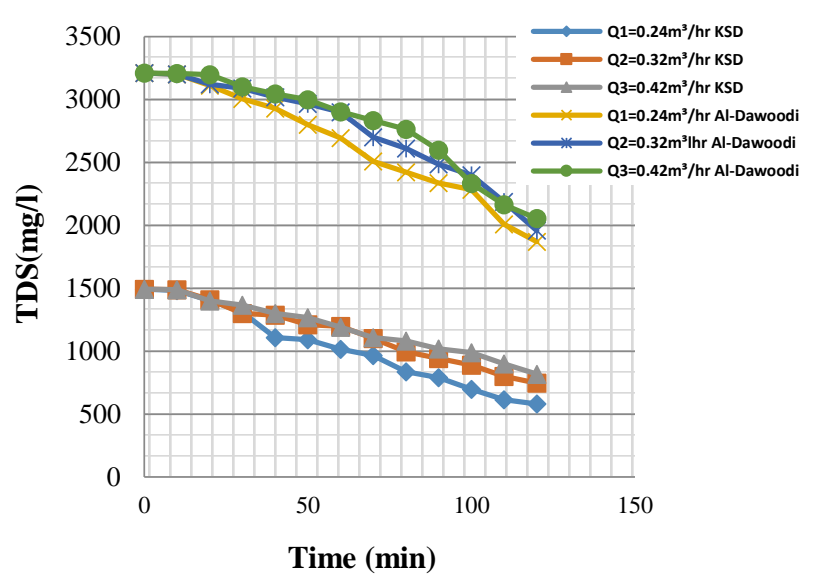

Figure 9. The removal TDS for (KSD and Al-Dawooodi).

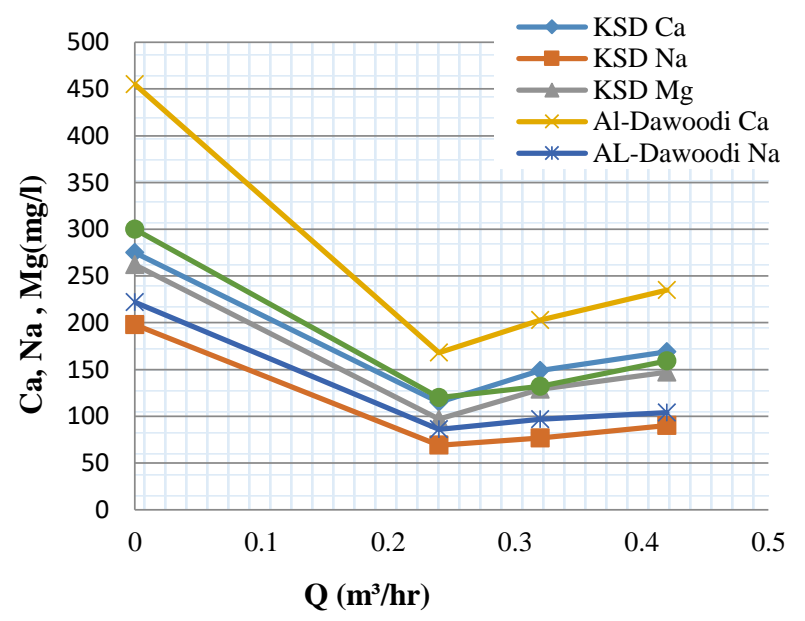

Figure 10. The removal ( $\mathrm{Na}, \mathrm{Mg}, \mathrm{Ca}$ ) for (KSD and $\mathrm{Al}-$ Dawooodi). 


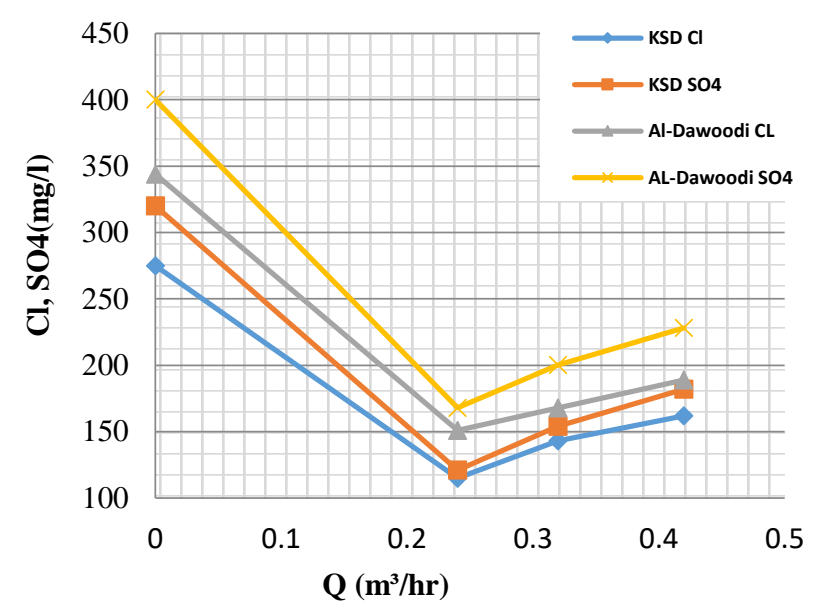

Figure 11. The removal efficiency of $(\mathrm{Cl}, \mathrm{So} 4)$ for $(\mathrm{KSD}$ and Al-Dawooodi).

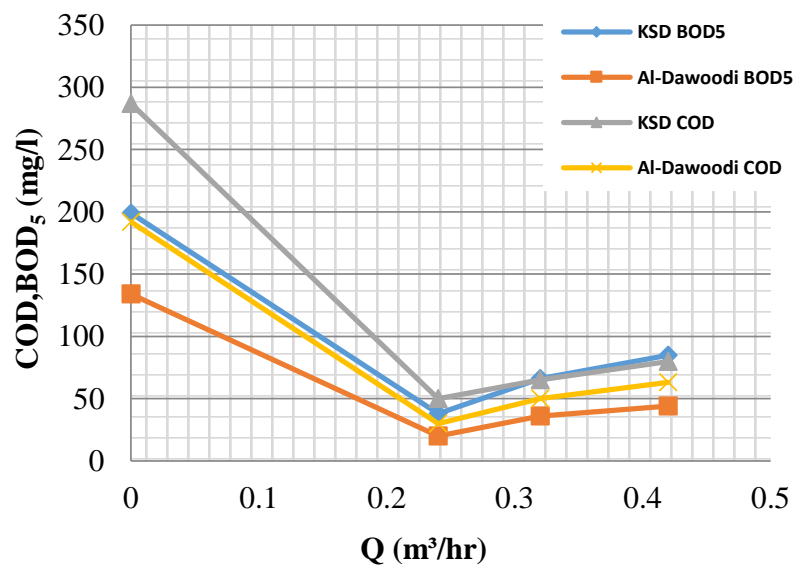

Figure 12. The removal $\left(\mathrm{COD}, \mathrm{BOD}_{5}\right)$ for $(\mathrm{KSD}$ and $\mathrm{Al}-$ Dawooodi).

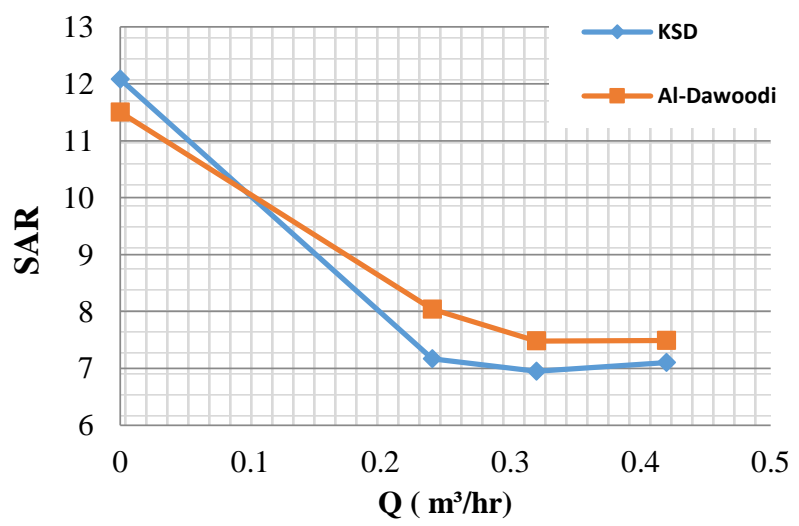

Figure 13. The removal $\mathrm{SAR}$ for $(\mathrm{KSD}$ and $\mathrm{Al}-$ Dawooodi).

\section{Conclusions}

The water of the two main agricultural irrigation drainage channels (KSD and Al-Dawoodi) is one of the water resources that can be invested for irrigation purposes. The research has studied the possibility and suitability of using treated water for irrigation by focusing on the most important determinants (EC, TDS, TSS, pH, $\mathrm{COD}, \mathrm{BOD}_{5}, \mathrm{SAR}$, the concentration of $(\mathrm{Ca}$, $\mathrm{Na}, \mathrm{Mg}, \mathrm{Cl}, \mathrm{So} 4)$ ) using multi-media filtration technology (commercial coal, coarse sand and mixed ion exchanger). The analysis results of water before treatment showed that water channels suffer from a rise in (salts, hardness by a high concentration of $\left(\mathrm{Ca}, \mathrm{Na}, \mathrm{Mg}, \mathrm{Cl}, \mathrm{So}_{4}\right)$, suspended materials, organic materials, while $\mathrm{pH}$ was within the acceptable standards for irrigation, the treatment showed the high efficiency of the multi-media filtration in the removal of salts, suspended solids, and organic materials by (EC, TDS, concentrations of (Na, $\left.\mathrm{Mg}, \mathrm{Ca}, \mathrm{Cl}, \mathrm{So}_{4}\right)$, SAR, TSS, COD, BOD $5, \mathrm{pH}$ ) that classified within the acceptable standards except for the removal of magnesium of AlDawoodi channel was not within acceptable standards. The results for both water channels (KSD and Al-Dawoodi) showed that treatment contributed to positive characteristics for water channels that can be reused for irrigation purposes, thus the multi-media filtration technology is a sustainable economic method, that materials are available locally, can be reused, and do not cause any environmental damage.

\section{Acknowledgments}

The authors would like to thank Sanitary laboratory, Al-Mustansiriya University /College of Engineering / Department of Environmental Baghdad - Iraq for all their support. 


\section{Conflict of interest}

The authors would like to note that the research does not cause any conflict of interest.

\section{Abbreviations}

$\begin{array}{ll}\text { EC } & \text { Electrical conductivity } \\ \text { TDS } & \text { Total dissolved solids } \\ \text { TSS } & \text { Total suspended solids } \\ \text { COD } & \text { Chemical oxygen demand } \\ \text { BOD }_{5} & \text { Biochemical oxygen demand } \\ \text { SAR } & \text { Sodium adsorption ratio } \\ \text { FAO } & \text { Food and Agriculture Organization }\end{array}$

\section{References}

1. Gulhane M. L., Yadav P. G. (2014). "Performance of the Modified Multi-Media Filter for Domestic Wastewater Treatment". Proceedings of 3rd IRF International Conference, Goa, India, ISBN: 978-9384209-15-5. p107-111

2. Irene F. G., Sergio L., M. C. Ruiz- Sanshyz, Juan V., Wenceslao C., Maria R. C., Alfonso D., Jose J. Pardo, Bruno C. L., Pilar M. (2020). "Trends and Challenges in Irrigation Scheduling in the Semi-Arid Area of Spain". Journal of Water. Vol. 12, Issue (3), doi:10.3390/ w12030785.

3. M. Michetti, M. Raggi, E. Guerra .D. Viaggi (2019). "Interpreting Farmers' Perceptions of Risks and Benefits Concerning Wastewater Reuse for Irrigation: A Case Study in EmiliaRomagna (Italy)". Journal of Water. Vol. 11, Issue (1), doi:10.3390/w11010108.

4. Saleh A., Weddings A. (2015)."The validity of the water of Al-Shamiya Al-Gharbi water drainage for irrigation purposes is evaluated". Engineering Sciences. Babylon University Journal. Vol. 23, Issue (1).
5. Wissam A. Abdullah (2015). "Water validity in the sector Mahmoudia - Jableh Essaouira from the general downstream drainage for irrigation purposes". Karbala Journal of Agricultural Sciences. Vol. 2 , Issue (2).

6. Kameran M. A. M. Salih (2012). "Role of different filter media in water purification and water treatment". Kurdistan Engineers Union. Branch: - Suleimanyah. ID No. : 5046.

7. V. Anusuya, R. Malathi, P. Subash Kumar, S. Sunil Barath (2017). "Characteristic Study on domestic wastewater by natural absorbents using multi-media filters technology". Sri Ramakrishna Institute of Technology. 6th National Conference on Innovative Practices in Construction and Waste Management. International Journal of Engineering Research and Modern Education. ISSN: 2455 - 4200, p 39-42.

8. Hasan S. Majdi, Mahdi S. Jaafar, Azher M. Abed (2019). "Using KDF material to improve the performance of multi-layers filters in the reduction of chemical and biological pollutants in surface water treatment". South African Journal of Chemical Engineering. Vol. 28, p 39-45.

9. A. Kharche, M. Dhomane, P. Mutyalwar, V.Gochade, S.Pangare (2019). "Use of Natural and Artificial Multimedia Filter as an Adsorbent for Filtration of Sewage Waste Water International". Journal of Engineering and Technology (IRJET). Vol. 06 Issue: 04. e-ISSN: 2395-0056. p-ISSN: 2395-0072.

10. Jay Patel (2016). "Ion Exchange Resins". XIII-Water-D-Ion Exchange Resins. Bachelor of Engineering Chemical Engineer. Mumbai, India.

https://www.researchgate.net/publication/30 5658612_ION_EXCHANGE_RESINS 
11. Fleifle, Ahmed T., Olive C.saavedra, Mohamed, (2013). "Treatment of agricultural drainage water via downflow hanging sponge system for reuse in agriculture". Journal of Water supply. Vol. 13, Issue (2), p 403-412.

12. M. Nasr, H. F. Zahran, 2015. "Assessment of agricultural drainage water quality for safe reuse in irrigation applications - A case study in Borg El-Arab Alexandria". Journal of Coastal Life Medicine. Vol. 3, Issue (3), p 241-244, doi: 10.12980/JCLM.3.2015J5-4.

13. Rashid, Kh. Abbas, A. W. Sabri, Abdel K. Abdel R., K. B. Nada, (2002). "Study of some physical and chemical properties of the Saddam River". Journal of Environment Research and Sustainable Development. Vol. 5, Issue (1), p 67-65

14. Alakm, F. Munhar, Abdel Moneim, I. Aqil (2011). "The effect of the main eastern Mezbel water on some physical and chemical properties of the Euphrates River in the city of Samawah - Iraq". Uruk Journal for Scientific Research. Vol. 4, Issue (1).

15. Mohammad F. Abid., Saadi K. Al-Naseri, Samirra N. Abdullah,2013. "Reuse of Iraqi Agricultural Drainage Water Using Nanofiltration". Journal of Membrane and Separation Technology, Vol. 2, Issue (1), p 53-62. DOI: $\quad 10.6000 / 1929-$ 6037.2013.02.01.6

16. L. A. Hussein (2014). "Study the Concentration of Some Heavy Metals in Water sediment and two types of plants in the eastern trocar for the Euphrates River (Al-Haffar) / Al-Diwaniyah". Journal of THI-QAR Sciences. ISSN: 19918690 , Vol.5, p 3-7.

17. R. I. Mohamed ( 2019)."Evaluation of the efficiency of irrigation and drainage projects in Al-Kifl region". Journal of the
College of Basic Education for Educational and Humanities. R. I. ISSN: 23043717 23128003. Issue (42). p 916-956.

18. Q. M. Salih Hassan (2012). "Evaluation of the drainage water quality at the North of Baghdad city and suitability for irrigation".Journal of Taqani, ISSN:1818653x, Vol.25, Issue (3), p A90A96.

19. Parjane, S., B., Sane, M., G. (2011). "Performance of greywater treatment plant by economical way for Indian rural development". International Journal of ChemTech Research Vol.3, pp 1808-1815

20. Katrina. A. Indarawis, Treavor H. Boyer (2013). "Superposition of anion and cation exchange for removal of natural water ions". Separation and Purification Technology Journal. Vol.118, p 112-119. DOI:10.1016/j.seppur.2013.06.044

21. H. Aisha, F. Al-Jabriya (2017). "Insulation by ion exchange and use in water purification". Academic Master Thesis, College of Technology, Chemical Engineering. University of the martyr Hama Lakhdar in Alwadi. Algeria .

22. Vikash R. Agrawal, Vikrant S. Vairagade, Amol P Kedar (2017). "Activated Carbon as Adsorbent In Advance Treatement of wastewater". IOSR Journal of Mechanical and Civil Engineering (IOSR-JMCE) eISSN: 2278-1684,p-ISSN: 2320-334X, Vol. 14, Issue 4, PP 36-40

23. L. K. Wulandari,, M.Bisri, D. Harisuseno , E. Yuliani (2019). "Reduction of BOD and COD of by using stratified filter and constructed wetland for blackwater treatment". IOP Conference Series: Materials Science and Engineering. Vol. 469, Issue (1), pages 012024

24. Kenneth A.Yongabi (2012). "A Sustainable low- cost phytofisinfectant - sand filter alternative for water purification". Ph.c 
Thesis of Philosophy, The School of Chemical Engineering Faculty of Engineering, Computer and Mathematical Sciences, University of Adelaide, Australia, $\mathrm{p} 43$.

25. Alia H. Salman (2009). "Geographical analysis of the drainage network in AlNajaf Governorate and ways to develop it". University of Kufa. Journal of Literature Kufa . Vol.1, Issue (4), p 270-325

26. Agc wp -multimedia filtration of process water, Sales, 2017.

https://www.slideshare.net/AGCInternation al/agc-wpmultimedia-filtration-of-processwater

27. Al-Jubouri, Hamid J., Z. Abdel-Wahab (2006). "The technology of planting date palm trees". FAO. p 505

28. G. N. Bou Bakr, F. A. Al-Azhar (2018). "Contribution to the study of assessing the validity of magnetic water for irrigation in Wadi Souf (Dawa farm, model)", Master Thesis, Faculty of Natural Sciences and Life .Department of Biology. University of the Martyr Hama Lakhdar El-Wadi. Algeria

29. H.A. El Nazer, S.A. Salman, A.A. Elnazer (2017). "Irrigation water quality assessment and a new approach to its treatment using photocatalytic technique: Case study Yaakob village, SW Sohag, Egypt". Journal of materials and Environmental Sciences ISSN : 2028-2508, Vol. 8, Issue (1), Page 310-317

30. H. Jeong , Ha. Kim, T. Jang (2016). "Irrigation Water Quality Standards for Indirect Wastewater Reuse in Agriculture: A Contribution toward Sustainable Wastewater Reuse in South Korea". Journal of Water . Vol.8, Issue (5) , p 169. Doi:10.3390/w8040169
31. N. Al-Abed, F. Abdulla, R. Zahrawi (2007). "Evaluation of irrigation water total suspended solids (TSS) on a farm scale". Journal of Archives of Agronomy and Soil Science.Vol.53, Issue(3), p 345-353. DOI: $10.1080 / 03650340701246008$.

32. Haifa Jassim Mohammed, 2014. "Study and comparison of adsorption of the two red dye Konku and violet cheeks Cong Red and Gentine violet on the surface of willow". Al-Qadisiyah Journal of Pure Sciences Vol. 20, Issue No: ISSN 1997- 2490.

33. N. Shakir Hadi (2013). "Comparison between the results of applications of the Canadian and Bhargava methods for irrigation water quality index at multilocations in Tigris River (A Case Study of Al-Amara Region)". Journal of Karbala University. ISSN: 18130410. Vol. 12, Issue (23), p 187-196

34. Iraqi Legislation Base. "The National Determinants System for the Use of Treated Wastewater in Agricultural Irrigation". No. 3, 2012. Iraqi Facts / No. 4260, p 8

35. Tahsin a. Zidan, Emad A. Muhammad Salih, Muhammad W. Waheed (2012). "An economic method for removing sulfides in sulfurous spring waters using activated charcoal the record is from the palm tree". Journal of Anbar University for Pure Sciences., ISSN: 1991-8941. Vol. 6, Issue (3), p 1-158

36. R. A. Milad, M. A. Bin Raqta, M. A. Ma`maref ,A. al-Sanusi (2019). "An evaluation study on the efficiency of the use of sand filters in wastewater purification". International Journal of the Court of Science and Information Technology. ISSN 2410-4256. Vol. 6, Issue (1), p 16-21

37. H. M. Maghraoui (1997). "Ion exchange". Journal of Science and Technology. ISSN: 1017 3056, Issue (44), p 1-50 
38. Rajesh Sharma. (2014)."Handbook on water and wastewater treatment". $5^{\text {th }}$ ed. , Ion Exchange Refreshing the planet. India.

39. B. Hanson, D. May, T. Hartz, G. Miyao (2008). "Drip Irrigation Processing Tomatoes". University of California, Agriculture and Natural Resources, Publication 3506. ISBN-13: 978-1-60107436-2, pp 58

40. L.G. James (1988). "Principles of Farm Irrigation System Design". John Wiley, New York, NY, pp. 260-299.

41. Saad A. Al-Jlil (2009). "COD and BOD Reduction of Domestic Wastewater using Actived Sludge, Sand filters and Actived carbon in Saudi Arabia". Biotechnology international peer-reviewed scientific journal. Vol. 8 , Issue (4) , p 473-477, DOI: 10.3923/ biotech.473.477

42. E. Woskowicz, Monika, Maciej, Anna K.,2019. "Hybrid processes combining microfiltration and adsorption exchange for dairy wastewater treatment". Journal of Machine Construction and Maintenance. ISSN 1232-9312. Vol.4, p. 75-82 